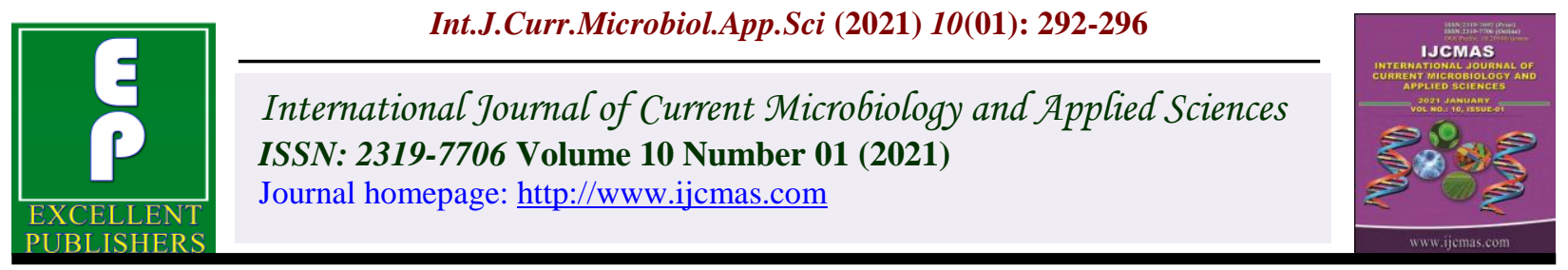

Original Research Article

https://doi.org/10.20546/ijcmas.2021.1001.036

\title{
Role of Phenolics in Resistance to Rhizoctonia solani f. sp. sasakii Causing Banded Leaf and Sheath Blight of Maize
}

\author{
S. E. Manjunatha*, K. B. Yadahalli, I. K. Kalappanavar and R. M. Kachapur \\ Department of Plant pathology, UAS, Dharwad, India \\ *Corresponding author
}

A B S T R A C T

Keywords

Phenols, Banded leaf sheath blight, Rhizoctonia solani,

Maize, Resistant

Article Info

Accepted:

04 December 2020

Available Online:

10 January 2021
A preliminary study aimed at investigating the possible role of phenolics in providing resistance against banded leaf and sheath blight of maize. The phenolic content in all genotypes of maize increased after infection. This increase was more prominent in resistant genotypes than in susceptible genotypes. The highest increase $(59.89 \%)$ of phenols was observed in the resistant inbred CI-5 inoculated with Rhizoctonia solani f. sp. sasakii (RsHS) isolate. Phenol accumulation ranged from 4.25 to $8.53 \mathrm{~g}$ per cent dry weight in inoculated diseased leaves and 4.17 to $5.33 \mathrm{~g}$ dry weight in uninoculated healthy leaves of 11 genotypes.

\section{Introduction}

Maize (Zea mays L.) or corn belongs to the Poaceae family. It is one of the third most commonly grown field crops in the world after rice and wheat. It is considered as 'Queen of Cereals' because of its high productive capacity in cereal crops. Given the fact that maize has a very high yield potential, one of the key disincentives for high grain yields is its susceptibility to a multitude of diseases that are detrimental to production and productivity. Approximately 112 maize diseases have been reported from different parts of the world, of which 65 are known to occur in India (Saxena, 2002). Among the many fungal diseases affecting the growth of maize, banded leaf and sheath blight (BLSB) caused by Rhizoctonia solani Kuhn f.sp. sasakii Exner is responsible for a huge loss of grain yield from 11 to 40 per cent and even to 100 per cent for some cultivars in certain warm and humid areas where factors are desirable for the pathogen. (Madhavi et al., 2011, Izhar and Chakraborty, 2013; Gao et al., 2014).

The symptoms occur on all the aerial parts of the plant, except the tassel, but the symptoms on the leaves appear as irregularly globular to elongated, reflective as water-soaked areas. The affected areas tend to be bleached; soon 
they become straw coloured and necrotic (Ahuja and Payak, 1982). Lesions enlarge quickly resulting in discoloured areas alternating with dark bands, which are typical symptoms of BLSB (Rani et al., 2013).

In the present scenario, management of BLSB is considered to be very critical because of the disease caused by Rhizoctonia solani f.sp. sasakii AG1-IA is the most prevalent and serious limiting factor for the efficient cultivation of maize in the world. Rhizoctonia solani is a soil-borne fungal pathogen with a very wide range of hosts and due to its genetically diverse nature; it is very hard to understand the background of BLSB resistance. Fungicides have indeed been extensively used to fight this fungus for the years, causing considerable concern for human health and the environment. As a result, attention was paid to alternative strategies to enhance crop resistance to invasive pathogens by identifying the genetic mechanisms responsible for an effective defense response. It is therefore essential to understand the biochemical pathways underlying between Rhizoctonia solani and maize and to plan long-term sustainable disease control strategies. The goal of this research is to create a biochemical basis for resistance in the screened population of maize genotypes by estimating the total phenols associated with the activation of the defense system.

\section{Materials and Methods}

In this study, two resistant genotypes involving one inbred and one hybrid (CI-5 and BIO9682), four moderately resistant genotypes involving three inbreds and one hybrid (CI-4, KDMI16, CM202, GHM1101), two moderately susceptible involving one inbred and one germplasm line (CM501 and GPM744) and three susceptible genotypes involving two germplasm lines and one hybrid (GPM649, GPM608 and DKC7074) were used to assess their biochemical basis for resistance and susceptibility. For this study, 40 days old plants were selected and were maintained in two sets with three replications each, one set is utilized for inoculation with Rhizoctonia solani f. sp. Sasakii RsKH isolate as per method suggested by Ahuja and Payak, (1978) and another set serves as control i.e., without inoculation. The samplings were taken from both inoculated and uninoculated plants after 8 days of inoculation and were used for estimating total phenols.

\section{Estimation of total protein}

$0.5 \mathrm{~g}$ of the inoculated and uninoculated plant tissue was crushed separately in liquid nitrogen and homogenised with $1 \mathrm{ml}$ sodiumphosphate buffer $\mathrm{pH}-7$ in a pre-chilled mortar and pestle at $4^{\circ} \mathrm{C}$. The homogenate was centrifuged at $12,500 \mathrm{rpm}$ for $20 \mathrm{~min}$ at $4^{\circ} \mathrm{C}$, and the supernatant was used as a protein source for the quantitative estimation in a spectrophotometer following the method developed by Lowry et al., (1951) and taking three replications for each reading.

\section{Preparation of enzyme extract}

$0.5 \mathrm{~g}$ of the inoculated and uninoculated plant tissue was crushed separately with $1 \mathrm{ml}$ buffer in a pre-chilled mortar and pestle at $4^{\circ} \mathrm{C}$. The homogenate was centrifuged at $12,500 \mathrm{rpm}$ for $20 \mathrm{~min}$ at $4^{\circ} \mathrm{C}$. Supernatant was used as an enzyme source.

\section{Estimation of total phenols}

Total phenol content was estimated by the procedure given by Malick and Singh (1980).An aliquot of $0.2 \mathrm{ml}$ of diluted alcohol extract $(1.0 \mathrm{ml}$ of alcohol extract diluted to $10.0 \mathrm{ml}$ ) was taken in a test tube. The final volume was made to $1.0 \mathrm{ml}$ with distilled 
water and $1.0 \mathrm{ml}$ of Folin-Ciocalteau reagent (1N) followed by $2.0 \mathrm{ml}$ of sodium carbonate solution (2\%) was added. The tubes were shaken well and heated in a water bath for exactly one minute and then cooled under running tap water. The blue coloured complex developed was diluted to $20 \mathrm{ml}$ with distilled water and its absorbance was read at $660 \mathrm{~nm}$ in a spectrophotometer. Different concentrations of $10,20,30,40,50 \mu \mathrm{g} / \mathrm{ml}$ of standard catechol $(50 \mu \mathrm{g} / \mathrm{ml})$ were used to prepare a standard curve of $\mu \mathrm{g}$ of phenols versus absorbance. The amount of phenols present in sample was calculated from the standard graph and expressed as gram per cent ( $\mathrm{g}$ of phenol in $100 \mathrm{~g}$ of tissue).

\section{Results and Discussion}

\section{Total phenol content}

The maize-Rhizoctonia interaction study showed that the phenol content (8.53 and 7.80 g dry wt.) was increased in inoculated resistant and moderately resistant genotypes respectively as compared to uninoculated genotypes (5.33 g dry wt.) and the lowest phenol content (4.25 and $5.38 \mathrm{~g}$ dry wt.) was registered in inoculated susceptible and moderately susceptible genotypes, respectively (Table 1 ).

The interaction between maize-Rhizoctonia, showed the increased phenol content in the inoculated resistant inbred i.e., CI-5 with 8.53 g per cent dry wt., which is followed by hybrid BIO9682 with $8.06 \mathrm{~g}$ per cent dry weight. Whereas, the lower phenol content (4.25 g \% dry wt.) was recorded in susceptible inoculated hybrid DKC7074 followed by germplasm line GPM608 with 4.28 g per cent dry wt. The per cent increase of the phenol content was higher in resistant inbred, CI-5 (59.89\%) and lowest (2.01) per cent increase was recorded in the susceptible hybrid, DKC7074 (Fig.1).

Table.1 Activity of phenols in selected genotypes of maize against $R$. solani under glasshouse conditions

\begin{tabular}{|l|c|c|c|}
\hline \multirow{2}{*}{ Genotypes } & \multicolumn{3}{|c|}{ Total phenol content (g per cent dry wt.) } \\
\cline { 2 - 4 } & Healthy & Diseased & Per cent Increase \\
\hline CI-5 & 5.33 & 8.53 & 59.89 \\
\hline BIO9682 & 5.58 & 8.06 & 44.44 \\
\hline CI-4 & 5.10 & 7.80 & 44.32 \\
\hline KDMI-16 & 4.95 & 6.84 & 38.23 \\
\hline CM202 & 4.93 & 7.18 & 37.63 \\
\hline GHM1101 & 4.91 & 6.77 & 37.92 \\
\hline CM501 & 4.89 & 5.88 & 20.26 \\
\hline GPM744 & 4.49 & 5.38 & 19.86 \\
\hline GPM649 & 4.76 & 5.56 & 16.91 \\
\hline GPM608 & 4.14 & 4.28 & 3.45 \\
\hline DKC7074 & 4.17 & 4.25 & 2.01 \\
\hline Factors & SEm \pm & CD @ 5 \% & \\
\hline G & 0.191 & 0.546 & \\
\hline T & 0.081 & 0.233 & \\
\hline GxT & 0.27 & 0.772 & \\
\hline
\end{tabular}

G: genotypes, T: treatment i.e., Healthy and Diseased, U: unit; 
Fig.1 Activity of phenols in different genotypes of maize against $R$. solanif. sp. sasakii

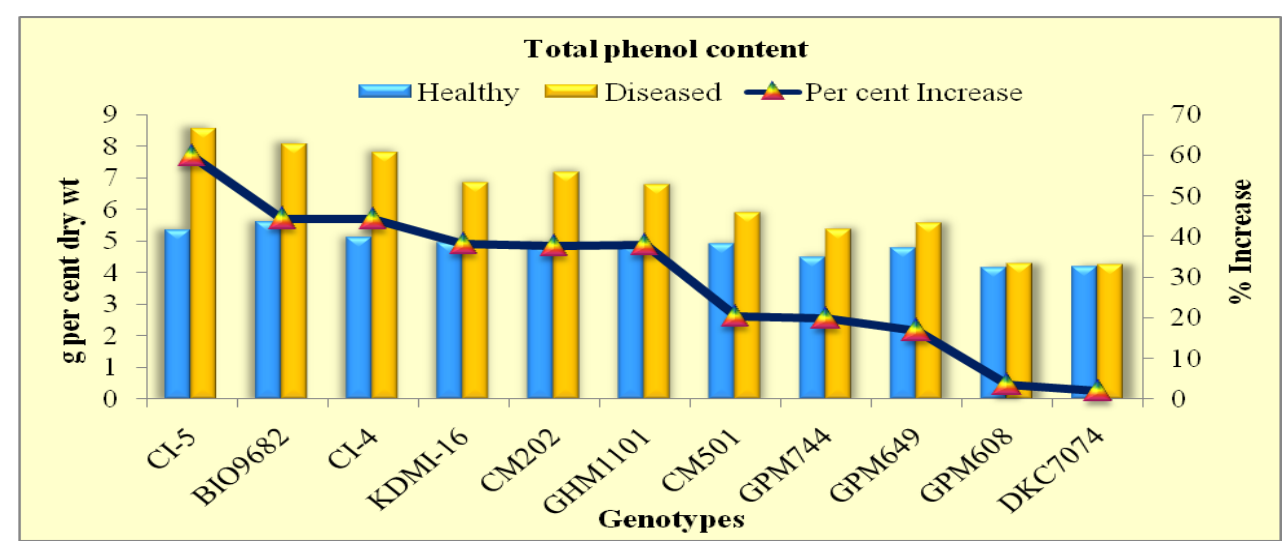

Overall, the present investigation showed the increased phenol content in resistant genotypes followed by moderately resistant, moderately susceptible and susceptible genotypes. The higher content of phenol in the resistant genotypes may be the possible reason for limiting the pathogenesis of the pathogen, thus reducing the disease, and vice versa in the susceptible genotypes, so that the disease was higher due to lower phenol content. However, the present findings were close to Dahima et al., (2014) stated that higher phenols in maize genotypes play a vital role in inducing resistance to BLSB in maize. Akhtar et al., (2011) found that phenolic content was higher in resistant cultivars compared to susceptible cultivars following BLSB infection. The presence of a high concentration of phenolic compounds is known to be one of the major factors for incompatible host pathogen interactions (Farkas and Kirlay, 1962). The plant cells synthesize phenol oxidising enzymes that oxidise phenols to toxic quinines upon pathogen infection, which play a key role in disease resistance (Vidyasekaran, 1988; Ashry and Mohamed, 2011) and it was evident from the present investigation. Phenols developed against the Rhizoctonia solani f. sp. sasakii therefore serve as a valuable trait for determining the disease resistance and worth exploring it in the maize plants.
In conclusion the studies on the expression of total phenols in the selected genotypes of maize under pathogenesis of Rhizoctonia solani revealed that the increased phenol as secondary metabolite did its job by restricting the pathogen through the conversion of phenolic compounds to toxic quinone compounds. From the present investigation it was concluded that, the biochemicals released during the maize-Rhizoctonia interaction may serves as a valuable tool for determining the resistance and susceptibility in the maize genotypes.

\section{Acknowledgement}

I am grateful to Dr. KiranMirajkar, Smt. Nagaratna SOlekar and Ms. Nanda., for providing the necessary facilities to carry out the work successfully in the Department of Biochemistry, University of Agricultural Sciences, Dharwad.

Conflict of interest: No conflicts of interest.

\section{References}

Ahuja, S. C. and Payak, M. M., 1978, A field inoculation technique for evaluating maize genotypes to BLSB. Indian Phytopathol., 31: 517-520.

Ahuja, S.C. and Payak, M.M., 1982, Symptoms and signs of banded leaf and 
sheath blight in maize. Phytopapasitica.10: 41-49.

Akhtar, J., Jha, V. K. and Lal, H. M., 2011, Post-infectional phenolic changes in maize due to Rhizoctonia solani f. sp. sasakii causing banded leaf and sheath blight. Indian Phytopathol., 64(3): 261264.

Ashry, N.A. and Mohamed, H.I. 2011, Impact of secondary metabolites and related enzymes in flax resistance and or susceptibility to powdery mildew. World J. Agri. Sci., 7: 78-85.

Dahima, V., Sharma, M. K., Khokhar.and Hooda, K. S., 2014, Post-infectional biochemical changes in maize leaves affected by banded leaf and sheath blight disease. Indian Phytopathol.,67(4) : 370-373.

Farkas, G.L. and Kirlay, Z.,1962, Role of phenolic compounds in the physiology of plant diseases and disease resistance.Phytopathol.,2(44): 105-150.

Gao, J., Chen, Z., Luo, M., Peng, H., Lin, H., Qin, C., Yuan, G., Shen, Y., Ding, H., Zhao, M., Pan, G. and Zhang, Z., 2014, Genome expression profile analysis of the maize sheath in response to inoculation to $R$. solani. Mol. Biol. Rep., 41: 2471-2483.

Izhar, T. and Chakraborty, M. 2013, Genetic analysis of banded leaf and sheath blight resistance (Rhizoctonia solani) in maize. J. Pharmacogn. Phytochem., 1:
$1-5$.

Lowry, O. H., Rosenbrough, N. J., Farr, A. L. and Randall, R. J., 1951, Protein measurement with the Folin phenol reagent. J. Biol. Chem., 193(1): 265275.

Madhavi, G.B., Bhattiprolu, S.L., Bharathi, S., Reddy, V. C. and Ankaiah, R., 2011, Studies on the management of banded leaf and sheath blight disease of maize (Rhizoctoniz solani f. sp. sasakii) using fluorescent Pseudomonads. In: Proc. $2^{\text {nd }}$ Asian PGPR Conf.Beijing P.R. China, pp 567-576.

Malick, C. P. and Singh, M. B., 1980, Plant Enzymology and Histoenzymology. Kalyani Publication, New Delhi, p. 286. Rani, V.D., Reddy, P.N. and Devi, G.U., 2013, Banded leaf and sheath blight of maize incited by Rhizoctonia solani $\mathrm{f}$. sp. sasakii and its management- A review. Int. J. Appl. Biol. Pharma. Tech., 4(4): 52-60.

Saxena, S. C., 2002, Bio-Intensive Integrated disease management of banded leaf and sheath blight of maize. In: Proc. $8^{\text {th }}$ Asian Reg. Maize Workshop: New Technol. New Millenn., Bangkok, Thailand, pp. 380-388.

Vidyasekaran, P. 1988, Physiology of Disease Resistance in Plants, Volume II. CRC Press, Florida, pp. 128.

\section{How to cite this article:}

Manjunatha, S. E., K. B. Yadahalli, I. K. Kalappanavar and Kachapur, R. M. 2021. Role of Phenolics in Resistance to Rhizoctonia solani f. sp. sasakii Causing Banded Leaf and Sheath Blight of Maize. Int.J.Curr.Microbiol.App.Sci. 10(01): 292-296. doi: https://doi.org/10.20546/ijcmas.2021.1001.036 